\title{
Development of Exposure to English Scale and Investigation of Exposure Effect to Achievement
}

\author{
Mustafa Gökcan (iD) 1, ${ }^{*}$ Derya Çobanoğlu Aktan (D) 1
}

${ }^{1}$ Department of Educational Measurement and Evaluation, Hacettepe University, Ankara, Turkey

\section{ARTICLE HISTORY}

Received: 16 September 2018

Revised: 7 February 2019

Accepted: 16 February 2019

\section{KEYWORDS}

Exposure to English, Language Acquisition, Structural Equation Modeling, Scale Development, English Achievement

\begin{abstract}
An absence of a scale for measuring exposure to the English language, which has a significant effect on English achievement, was detected in the literature. For this reason, in this study, a six-dimensional scale was developed to detect the level of English language exposure and its construct validity was tested. The factor structure of the scale was determined by exploratory factor analysis with the data collected from 784 university students, 726 of whom are undergraduate and 58 of whom are Master's and Ph.D. students. Confirmation of the factor structure of the scale was carried out with a measurement model specified in a structural equation model. A structural equation modeling study was performed along with 233 students from English preparation classes at a university. In the structural model, the effect of exposure to English on the students' scores received from writing in English, speaking in English and the total score (grammar, vocabulary, reading and listening scores) was examined. It was found that exposure to English has a significant effect on all of the three variables. Exposure to English explained the variance of the speaking variable most, while that effect is the least for the writing variable.
\end{abstract}

\section{INTRODUCTION}

It is a fact that the significance of speaking a language is indisputable and so it is at the heart of life. We use language for expressing our feelings, for achieving our goals and even just for pleasure. Some people do all of these things not with a single language but with two or more languages. Even we can say that now monolingual people are one of the endangered species in most countries of the world. A second language affects people's careers, their future, their ongoing lives, and even their identities. For this reason, it is an important duty for educators to make the process of second language learning more efficient and easier for language learners (Cook, 2008). For this purpose, in foreign language education, theories have been put forward and various methods based on these theories were applied. During the times when there were significant methodological shifts and when the methods based on memorizing grammar rules were replaced with the ones focused on meaning, Stephen Krashen's ideas and the hypotheses

CONTACT: Mustafa Gökcan $₫$ gokcan.m@gmail.com $\equiv$ Department of Educational Measurement and Evaluation, Hacettepe University, Ankara, Turkey 
have been very influential and methods grounded on Krashen's suggestions have been developed and employed widely around the world (Lightbown \& Spada, 2006). As Ellis (2015) noted, Krashen's language acquisition theory had an influential effect on language pedagogy and frequently referred in the books serving as guides for English language teachers. By this means, most of the English language teachers have had the chance to know him.

The importance of Krashen in teaching English as a second or foreign language can be understood from following notes of the Cook. Cook (2008) speaks about two geographical separations of teaching conversational skills in English language teaching. In teaching methods originated from the UK, from the very beginning of the course, speaking the language is demanded besides listening to it. However, in language education systems based on the US or more precisely based on Krashen, it is given importance to listening without speaking. Krashen (2009) emphasizes that speaking English is not a skill to be learned but an outcome emerging by itself after being exposed to an ample amount of comprehensible input. Krashen, in the area of language teaching, is one of the linguists that does not give too much importance to language production. Despite widely being criticized for this reason, Krashen's ideas achieved a significant breakthrough in the studies on language acquisition and simply became a turning point in the area (Mitchell, Myles, \& Marsden, 2013). The issue that is mostly emphasized in Krashen's own language acquisition theory is the comprehensible input. That is to say, for language acquisition, the most important factor is the amount of input that the learner confronted during the learning process. Those who are more exposed to English and have frequent language exposure acquire the language more easily (Gökcan \& Çobanoğlu Aktan, 2018).

According to the literature, exposure to a language, without any doubt, is a vital ingredient in the learning of any language. Along these lines, Harmer (2007) states that fact as, "As far as we can see, children are not taught language, nor do they set out to learn it consciously. Rather they acquire it subconsciously as a result of the massive exposure to it" (p. 49).

Exposure to language has that same importance in second language acquisition too. The role of exposure is emphasized under the name of "comprehensible input" in Stephen Krashen's theory of language acquisition. (Krashen, 1982). His theory consists of five main hypotheses namely, the acquisition-learning hypothesis, the natural order hypothesis, the monitor hypothesis, the input hypothesis, and the affective filter hypothesis. In the first hypothesis, he emphasizes the distinction between learning a language and acquiring a language. Acquiring a language is a subconscious process, and it is the process we undergo while acquiring our mother tongue. According to Krashen, that process is also possible in second language acquisition, once the individuals get an ample amount of comprehensible input and they focus on meaning rather than form as they do when they acquire their first language. In the second hypothesis, some research findings, indicating that there is a predictable and natural order throughout the acquisition of the grammatical structures and the rules of English, are given. In the monitor hypothesis, Krashen states the role of language learning in the context of second language acquisition. He claims that the learned part of language has an influence on our acquired knowledge, and the former one edits or monitors the utterances initiated by the latter one. In the fourth hypothesis, the input hypothesis, the focus is on enabling the second language learners to get sufficient amount of comprehensible input that is one step beyond their current level of language proficiency. In his last hypothesis, he defines the roles of some affective variables such as attitude and anxiety in second language acquisition context. A filter called "Affective filter", which can be defined as a mental block formed by the negative attitude towards English and high foreign language anxiety may hinder the acquisition of the comprehensible input. In summary, the focus of Krashen's theory of language acquisition is 
exposure to the target language. By exposure to a sufficient amount of comprehensible input and low affective filter, one can acquire the target language successfully.

Coupled with the theoretical background supporting the important role of exposure in second language acquisition, in the literature, there are also a number of studies investigating the effect of language exposure on English achievement. Few of them will shortly be reviewed here.

\subsection{Review of Literature}

Olsson (2012) found that there is a significant positive correlation between exposure to English and English course grades of Swedish $9^{\text {th }}$ graders and their scores from the writing section of a national English exam. Djigunovi'c, Nikolov, and Ottó (2008) compared the English achievement of Croatian and Hungarian students. In their study, as the indicator of success in language learning, they chose an English exam, which has for sub-tests as reading comprehension, listening comprehension, speaking, and writing. They looked at whether there are differences in the mean scores obtained from all the subtests between the two countries. Croatian students were found more successful and it was observed that the factors like starting language learning early, more hours for English course, a classroom with fewer students, which are presented as the keys for success in language acquisition, are in fact not that effective. It was stated that the real reason that made the Croatian students more successful than Hungarian students is actually Croatian students' higher level of exposure to English. Derwing, Munro, and Thomson (2007) worked with two groups of elite Canadian immigrants whose jobs vary from doctors to engineers and scientists. Each group has sixteen members, in one group their mother tongue is Mandarin, and in the other group, it is Slavic languages. Over the course of two years, the data was collected at certain intervals and it was investigated whether there was a change in their listening to English, listening comprehension and speaking accuracy. While increases were observed among the Slavic group which was also found to be exposed to English more, no increase was seen among the Mandarin-speaking group. Wolf, Smit, and Lowie (2017) investigated the effect of starting learning English earlier on oral fluency. They found that although starting earlier has an effect, exposure to English outside the classroom is a more effective factor. In his very recent study, Peters (2018) also found that the effect of exposure to English on English achievement is more than the effect of length of the instruction.

In the above-mentioned studies to determine the level of language exposure, including Derwing et al. (2007), all the researchers used different questionnaires without any reliability and validity studies. Derwing et al. (2007), however, just used a limited questionnaire, which measures exposure outside the classroom. In their study (Gökcan \& Çobanoğlu Aktan, 2016) developed a scale to measure the English exposure levels for elementary students. However, there is no scale to measure university students' exposure to the English language. In this study, developing a scale for university students is aimed.

As it is seen in the aforementioned studies, despite the fact that the effect of exposure to English on general English achievement or on its components like speaking, writing and reading or listening comprehension was investigated separately, its effect on writing, speaking, reading and listening comprehension in English has not been examined at once. For this reason, in this study firstly a scale that will measure the level of language exposure of university students is developed. Then the effect of exposure on speaking, writing and the total score (an examination that includes questions related to reading and listening comprehension, grammar and vocabulary knowledge) is analyzed with structural equation modeling. Although the use of SEM which is an advanced statistical method has increased recently in the language acquisition studies (Winke, 2014), it is still very rare when compared to other analysis methods (Hancock $\&$ Schoonen, 2015). The fact that there are many complex variables in the process of language acquisition requires robust statistical methods like SEM (Winke, 2014). In this study, by 
employing SEM, first of all, the factor structure of the exposure scale was confirmed and then the effect of the exposure on writing, speaking and total scores of the university students was investigated with a structural model.

\section{METHOD}

The purpose of this study is to develop a scale to measure Exposure to English and to investigate the effect of language exposure to language achievement. In the study, first of all, item pool was written based on literature and previous studies, and the exploratory factor analysis (EFA) was conducted for the construct validity of the scale. The confirmation of the factor structure obtained after EFA was carried out with a measurement model specified in a structural equation modeling analysis with data collected from a different sample. Then a structural model was specified to investigate the effect of exposure to English achievements of the university students. The analysis of EFA was done with SPSS 23 and the analysis of SEM was performed with Mplus 7. The details of the analysis are explained after the specifications of the participants.

The data for this study were collected in two separate times. The first data set was used in the scale development and the second one used in the structural modeling part. The participants of the first part of the study were 810 (363 male, 447 female) university students, 750 of whom are undergraduate and 60 of whom are Master's and Ph.D. students. They were aged between 18 and 32 years and enrolled in various faculties of a private university (but mainly in the faculty of law, economics and administrative sciences, and engineering). The students who participated in the second part of the research were 247 students receiving their English preparation in a state university.

In the process of developing the exposure to English scale firstly 27 scale items that represent the possible sources and the ways from which the students are considered to get comprehensible input were written by reviewing the related literature and Gökcan and Çobanoğlu Aktan's (2016) scale for exposure to English. This scale for elementary students has five sub-factors (i.e. exposure through friends, school, text, media, software). The reliability coefficients (Cronbach's alpha) of the factors were reported as $901, .889, .769, .741, .765$ respectively and the scale consisted of twenty items. In addition to the items that are found in elementary student exposure scale, items related to exposure through English-speaking foreigners were added in the current study. It was thought that sources of exposure are different for elementary students than university students. Those students are most likely to have experiences like traveling abroad or talking to tourists.

To provide evidence related to content validity, the first form of the scale was presented to five experts reviewers (two English teachers, one expert who has a Ph.D. in foreign language education and two experts who have Ph.D. in the program of measurement and evaluation in education). According to the experts, items of the scale were appropriate, thus this first form given in Appendix 1 was administered to 810 university students without any modification.

The EFA study was carried out with those data and after the analysis, the second form of the scale given in Appendix 2 was obtained. Then by using the second form, a study of structural equation modeling in which the construct of exposure to English was handled as an exogenous variable was performed. As endogenous variables, speaking, writing and booklet scores of 247 students receiving their English preparation in a university were included in the model.

\subsection{Data Analysis}

Before conducting exploratory factor analysis, the suitability of data for factor extraction was examined. For this purpose, Kaiser-Meyer-Olkin (KMO) to examine the sample size adequacy for factor analysis and the Bartlett sphericity test (which shows that the data significantly differs 
from the identity matrix and the data belongs to multivariate distribution) were calculated. The data with missing values were excluded from the analysis. According to Tabachnick and Fidell (2013), if missing values are distributed randomly, observed in different variables and few in number when compared to the complete data $(<\% 5)$, excluding the observations including missing data won't cause a problem. The analysis was carried out with 784 students after the answers including missing data were excluded from the study. The total scale scores of the students were converted to $\mathrm{z}$ values in order to detect if there are any outliers. According to Tabachnick and Fidell (2013), if the latent constructs that the items on which EFA is performed will form are foreseen beforehand, Principal axis factoring should be preferred and if the factors are expected to have statistically significant correlations between each other oblique rotation methods should be applied. In addition to this, Brown (2015) states that oblique rotation provides a more realistic representation of factors. Even if the factors are not correlated, according to Brown oblique rotation will produce the same results by orthogonal rotation. On the contrary, when the factors are correlated, the oblique rotation will produce more accurate results.

The Kaiser criterion was employed for determining the number of important factors. According to the Kaiser criterion, the factors having eigenvalues higher than 1 are regarded as important ones and those whose values are below 1 are not taken into consideration. Moreover, this method is suggested for determining the factor structures of the scales that have 20-50 variables (Alpar, 2011). In addition to the Kaiser criterion, scree plot of the eigenvalues was examined to determine the number of the factors.

The reason behind our choice of Kaiser criterion is the will to represent the sources of exposure to English separately. The item removal process was carried out based on the recommendations in the literature (Comrey \& Lee, 1992; Çokluk, Şekercioğlu \& Büyüköztürk, 2014; Thompson, 2004). Firstly, the items which did not load significantly on any factor were removed. Then the items with factor loadings less than .50 were deleted one by one. And lastly, the complex items that cross-load too highly (e.g., > .32) on two factors were also removed.

To determine the internal consistency of the Exposure to English Scale, Cronbach alpha coefficient was calculated for each sub-factors.

In the second part of the study, before starting structural equation modeling, the data were screened and the assumptions for multivariate statistics were tested. The univariate outliers and Mahalanobis distance were checked. The SEM analysis was conducted with the data of 233 students. The assumptions of linearity multicollinearity, univariate and multivariate normality were examined.

The structural model in this study could be described as a partially latent structural regression model (Kline, 2016), because every variable in its structural part is not latent with multiple indicators. In our model, exposure to English is a latent construct measured by multiple indicators, but the variables of speaking, writing, and booklet are single-indicator measurements. Four model-fit measures which are recommended by Kline (2016) were used to assess the model's overall goodness-of-fit: the ratio of Chi-square $\left(\chi^{2}\right)$ to degrees-of-freedom (d.f.); comparative fit index (CFI); root mean square error of approximation (RMSEA); and standardized root mean square residual (SRMR).

\section{FINDINGS}

\subsection{Findings related to EFA}

Before conducting exploratory factor analysis, the Kaiser-Meyer-Olkin (KMO) and Bartlett sphericity tests results given in Table 1 were examined. The value of KMO .935 indicated that the sample size is adequate for factor analysis. The Bartlett sphericity p-value for the test was 
below .05 and this shows that the data significantly differs from the identity matrix and the data belongs to multivariate distribution. According to these results, the data collected for this study is suitable for factor analysis (Can, 2014; Çokluk et al., 2014;).

The data with missing values were less than $\% 5$ of the total data, therefore, they were excluded from the study. The factor structure of the scale was examined with the data of 784 students. The converted $\mathrm{z}$ scores of the data indicated that there were no outliers because all the $\mathrm{z}$ scores were between -4 and +4 .

Table 1. KMO and Bartlett's Test

\begin{tabular}{llr}
\hline Name of the test & Value \\
\hline Kaiser-Meyer-Olkin Measure of Sampling Adequacy. & .935 \\
& Approx. Chi-Square & 13.248 \\
Bartlett's Test of Sphericity & df & .351 \\
& Sig. & .000 \\
\hline
\end{tabular}

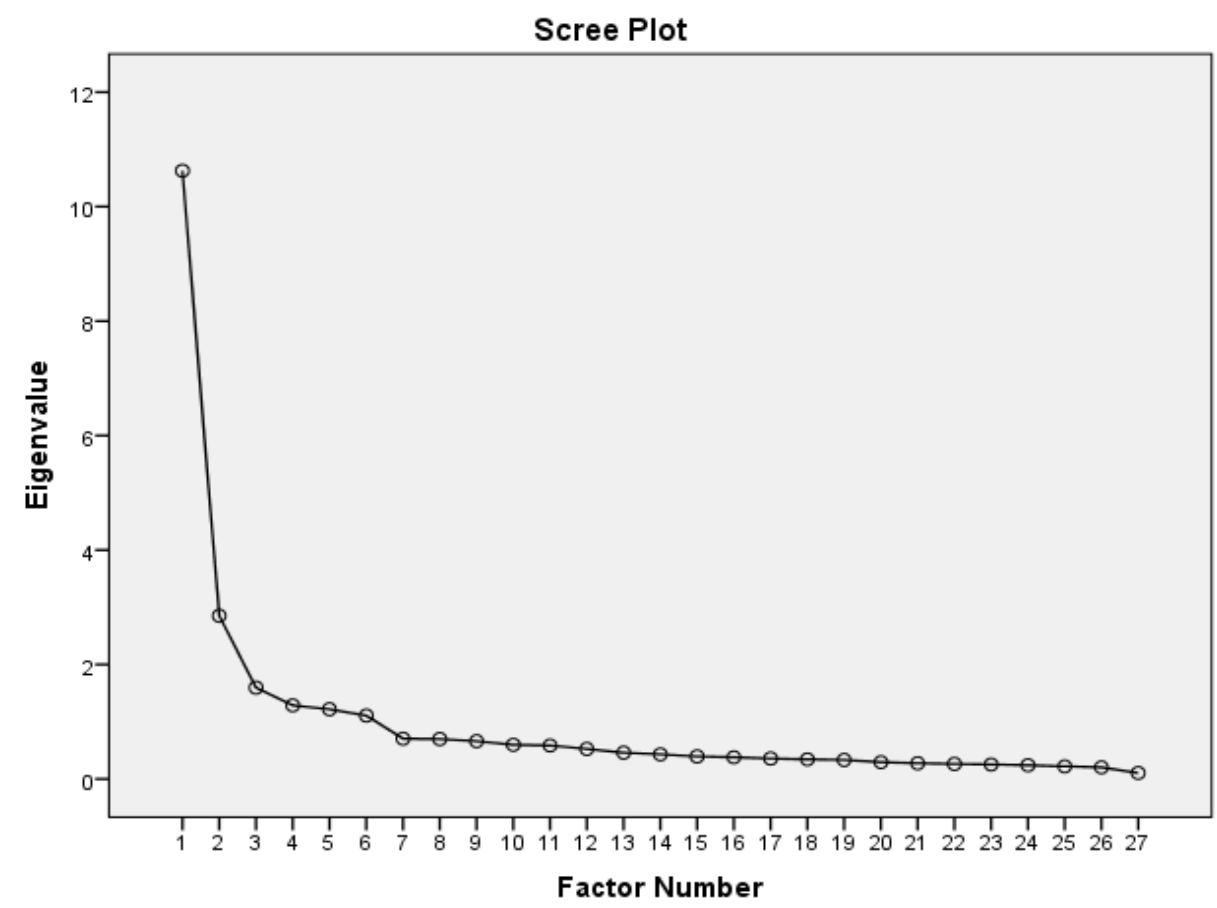

Figure 1. Scree Plot

For the factor extraction, principal axis factoring was performed. Scree plot and Kaiser criterion were used to determine the number of factors. As it is seen from the scree plot in Figure 1, there are 6 points above the point where the curve starts to flatten. Furthermore, there are six factors with eigenvalues higher than the one. This shows that the number of the factors to be extracted should be determined as six (Costello \& Osborne, 2005; Thompson, 2004).

Six factors obtained as a result of Kaiser criterion were thought to be fruitful because it provided factors to represent the sources of exposure to English separately. The item removal was done according to the literature (Comrey \& Lee, 1992; Çokluk et al. 2014; Thompson, 2004). The items, which did not load significantly on any factor, and the items with factor loadings less than .50 and cross-loaded items were removed. Consequently, five items were deleted and we obtained a scale with 22 items. In Table 2, the eigenvalues of the six factors and the variances explained by the factors are given. 
Table 2. Initial Eigenvalues and the Total variance explained by the six factors.

\begin{tabular}{cccc}
\hline Factor & Eigenvalue & \% of Variance & Cumulative \% \\
\hline 1 & 8.251 & 37.505 & 37.505 \\
2 & 2.592 & 11.781 & 49.286 \\
3 & 1.485 & 6.751 & 56.038 \\
4 & 1.276 & 5.800 & 61.837 \\
5 & 1.102 & 5.009 & 66.847 \\
6 & 1.053 & 4.786 & 71.632 \\
\hline
\end{tabular}

The six factors extracted by EFA were named as Text, School, Media, Friends \& Family, Computer, and Foreigners. Although one factor consists of just two items, it was retained in the scale. This is because it is stated that, in multidimensional scales, if the factor loadings of the two items are high and there is no difficulty in interpreting and naming the factor, the factor including two items may not be removed from the scale (Worthington \& Whittaker, 2006). The suggestions in the literature for having at least three indicators per factor are found under the title of model identification. The CFA models may be under-identified, just-identified or overidentified, and the parameters of the model can only be estimated when the model is overidentified. In CFA models, the degrees of freedom (df) equal to the number of parameters in the input matrix minus the number of unique free parameters which are estimated from that matrix, and the model is over-identified when the $d f$ for the model is positive. In other words, to be able to get over-identified CFA models, the number of parameters in the input matrix should be more than the number of freely estimated parameters of the CFA model. While the parameters of the input matrix are the variances of the indicators and the covariances between them, the parameters of the CFA model to be freely estimated are the factor loadings, factor variances, and covariances, error variances and covariances of the indicators etc. If there is only one dimension, the latent construct should be measured by at least three observed variables to meet the conditions of identification. However, if the scale consists of more than one dimension, models, which include two indicators per factor, can also be over-identified. There will be a problem of empirical under identification if the correlations between the factors are equal to 0 . However, if the factors are correlated then the model won't have an identification problem, and the parameters of the CFA model can be estimated with ease (Brown, 2015; Tabachnick \& Fidell, 2013). In our case, the scale is multi-dimensional and there are significant correlations between the dimensions. Moreover, the CFA model in which the dimension with two indicators is included produced good model fit indices.

Table 3. Correlation coefficients between factors.

\begin{tabular}{|c|c|c|c|c|c|c|}
\hline Factor & 1 & 2 & 3 & 4 & 5 & 6 \\
\hline 1 & 1.000 & .431 & .580 & .515 & .688 & .574 \\
\hline 2 & .431 & 1.000 & .249 & .535 & .397 & .294 \\
\hline 3 & .580 & .249 & 1.000 & .322 & .597 & .448 \\
\hline 4 & .515 & .535 & .322 & 1.000 & .445 & .372 \\
\hline 5 & .688 & .397 & .597 & .445 & 1.000 & .544 \\
\hline 6 & .574 & .294 & .448 & .372 & .544 & 1.000 \\
\hline
\end{tabular}


In Table 3, the correlation coefficients of the factors are presented. Tabachnick and Fidell (2013) suggest considering the factor correlation matrix for correlations around .32 and above. According to them, if correlations are greater than .32, then oblique rotation should be used, unless there are compelling reasons for orthogonal rotation. As it is seen from the table, most of the correlation coefficients between the factors are high, and above .32. Therefore, the oblique rotation was preferred as factor rotation method.

In Table 4 the final pattern matrix was given. The item numbers used in this matrix were according to the first form of the scale presented in the Appendix 1.

Table 4. Final pattern matrix.

\begin{tabular}{lcccccc}
\hline & 1 & 2 & 3 & 4 & 5 & 6 \\
\hline M23 & .967 & & & & & \\
M22 & .905 & & & & & \\
M24 & .778 & & & & & \\
M14 & .628 & & & & & \\
M13 & .516 & & & & & \\
M25 & .478 & & & & & \\
M10 & & .922 & & & & \\
M6 & & .765 & & & & \\
M9 & & .738 & & & & \\
M7 & & .636 & & & & \\
M17 & & & .960 & & & \\
M18 & & & .938 & & & \\
M16 & & & .719 & & & \\
M1 & & & & .707 & & \\
M2 & & & & .653 & & \\
M3 & & & & .625 & & \\
M8 & & & & .569 & & \\
M26 & & & & & .967 & \\
M27 & & & & & .647 & \\
M11 & & & & & & \\
M5 & & & & & & \\
M4 & & & & & & \\
& & & & & & \\
& & & & & \\
\end{tabular}

The items numbered as 13, 14, 22, 23, 24 and 25 loaded on Text dimension, the ones numbered $6,7,9,10$ loaded on School dimension, the ones numbered 16, 17, 18 loaded on Media dimension, the ones numbered 1,2,3 and 8 loaded on Friends \& Family dimension, the ones numbered 11, 26, 27 loaded on Computer dimension and lastly the ones numbered as 4 and 5 loaded on Foreigners dimension. Reliability coefficients (Cronbach's alpha) for each factor were calculated as $.883, .824, .921, .786, .773$ and .704 respectively.

\subsection{Findings related to SEM}

Before starting the study of structural equation modeling, data screening was also applied again and the assumptions that have to be examined in multivariate statistics were tested. Missing values were detected in answers of 14 students and these data were removed from the study. In the data, there was not a univariate outlier. Since one of the student's answers' Mahalanobis distance was higher than the related critical chi-square value, the data from this student was considered as a multivariate outlier and it was excluded from the analysis. The SEM analysis was conducted with the data of 233 students. While testing the assumptions, there was not any 
problematic variable in terms of linearity and multicollinearity, but the assumptions of univariate and multivariate normality couldn't be met. Normality tests were carried out with AMOS 23 and, in Appendix 3, both the univariate and multivariate normality test results are given. When we look at the skewness and kurtosis values estimated for each variable in the structural model, it is seen that there are some values indicating univariate non-normality (i.e. skewness and kurtosis values above 1). According to Brown (2015) "although univariate normality does not ensure multivariate normality, univariate non-normality does ensure multivariate non-normality" (p. 347). In other words, if our data does not meet the conditions of univariate normality, it will also not be multivariate normal data. There is, therefore, no need to investigate multivariate normality further, but Mardia's (1970) coefficient of multivariate kurtosis is also reported in the normality test results for showing another evidence of multivariate non-normality. A multivariate kurtosis value more than 10 and its critical ratio value above 1.96 together indicate a multivariate non-normal data (Byrne, 2010; Gao, Mokhtarian, \& Johnston, 2008; UTEXAS, 2018). For our data, the values were estimated as 66,221 and 14,307 respectively, which shows the multivariate distribution of the data is not normal. Since the data is not normally distributed, MLR (Maximum Likelihood Estimation with Robust Standard Errors) was used as the estimation method. MLR enables conducting analysis with the data sets for which normality assumption cannot be met (Muthén \& Muthén, 2010).

Table 5. The intervals for model fit indices and values calculated for the models.

\begin{tabular}{lcccc}
\hline Model Fit Indices & $\left(\chi^{2} / \mathrm{df}\right)$ & RMSEA & CFI & SRMR \\
\hline Good Fit & $0 \leq \chi^{2} / \mathrm{df} \leq 2$ & $0 \leq$ RMSEA $\leq .05$ & $.95 \leq$ CFI $\leq 1.00$ & $0 \leq$ SRMR $\leq .05$ \\
Acceptable Fit & $2 \leq \chi^{2} / \mathrm{df} \leq 5$ & $.05 \leq$ RMSEA $\leq .10$ & $.90 \leq$ CFI $\leq .95$ & $.05 \leq$ SRMR $\leq .10$ \\
$\begin{array}{l}\text { First Measurement } \\
\text { Model }\end{array}$ & 2.43 & .078 & .852 & .077 \\
$\begin{array}{l}\text { Modified Measurement } \\
\text { Model }\end{array}$ & 1.84 & .060 & .917 & .069 \\
Structural Model & 1.69 & .054 & .920 & .069
\end{tabular}

Firstly, a measurement model was specified to confirm the factor structure of the data belonging to exposure to language scale which was used in the study. Since the fit indices calculated for the first measurement model did not produce acceptable values for good model fit, the modifications, which cause the most decrease in chi-square value, were carried out after examinations of the modification indices. Firstly, item 4 (My schoolmates speak English) was deleted from the model, because it cross-loaded on the dimension of School. Then the errors of item 14 (I read web pages in English) and item 15 (I follow blogs in English) were allowed to co-vary. After these modifications which were also conceptually reasonable, the measurement model produced acceptable and good model fit indices $(\chi 2 /$ d.f. $=1.839$, RMSEA $=0.060, \mathrm{CFI}$ $=0.917$, SRMR $=0.069)$ (Bollen, 1989; Byrne, 2010, 2012; Kline, 2016). The model fit indices estimated for the first measurement model, the modified measurement model, and the structural model are given in Table 5 . 


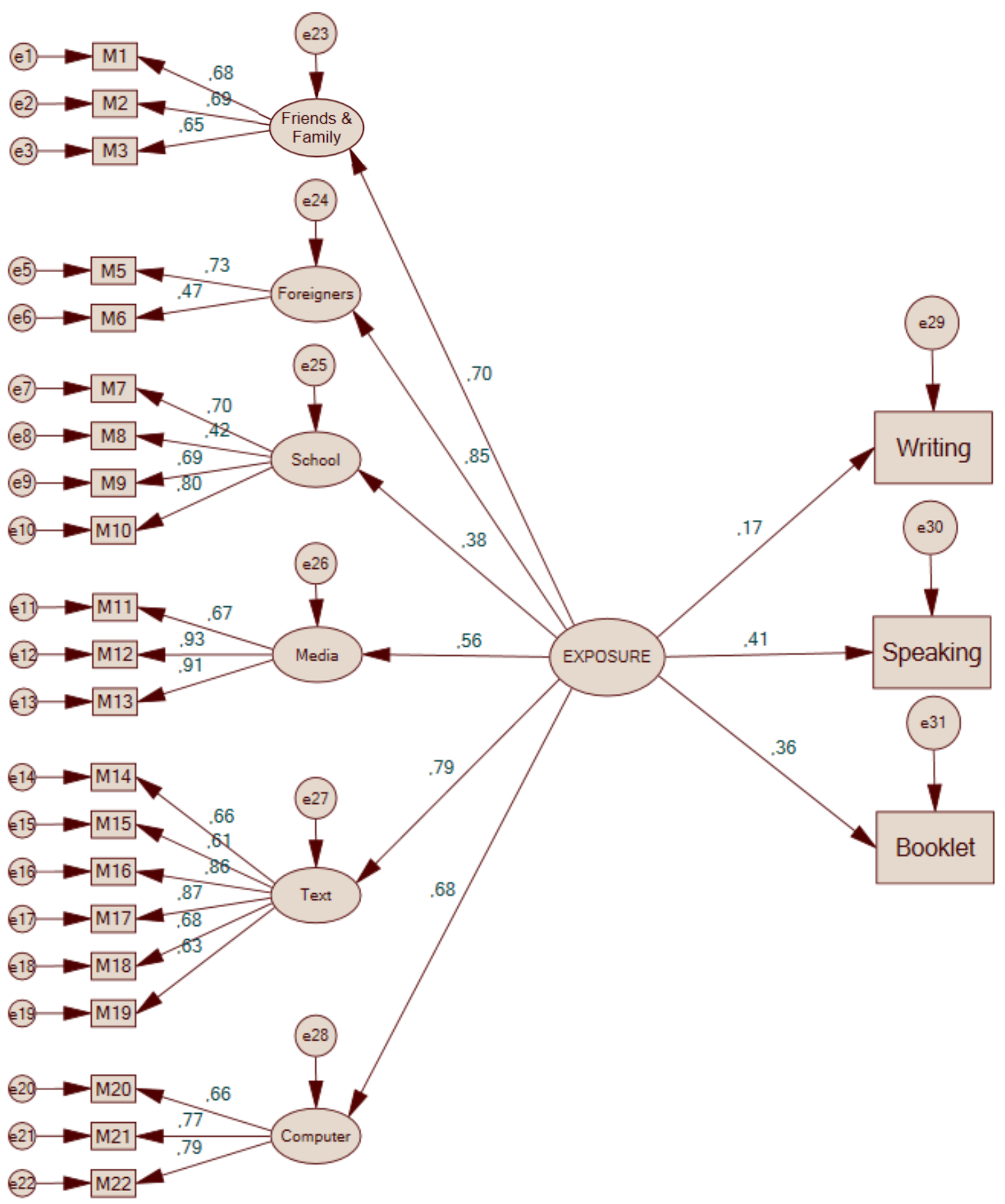

Figure 2. Structural Model

After the measurement model was analyzed, a structural model was formed in which the variable of exposure was specified as the exogenous latent variable and the variables of writing, speaking and booklet were included as endogenous dependent variables. The structural model produced good and acceptable fit indices $(\chi 2 /$ d.f. $=1.690, \mathrm{RMSEA}=0.054, \mathrm{CFI}=0.920$, SRMR $=0.069)$ without any need for a modification. The values estimated for the parameters in the structural model are given both on the diagram in Figure 2 and in Table 6. For each value calculated for the parameters in the structural model the $\mathrm{p}$ values are estimated below .05 and therefore they are all statistically significant as in the measurement model. 
According to the results obtained from the structural model, exposure to English has significant effects on speaking, writing and booklet scores of the students. While the variable which exposure affects most is speaking $(\gamma=.405)$, the one which is affected least is the writing variable $(\gamma=.174)$. To be able to make interpretations about the level of the effects on the dependent variables, the standardized measure of effect size $\left(\mathrm{f}^{2}\right)$ which was suggested to use in regression-based studies was also calculated (Cohen, 1988) and they are given in Table 6 too. It is observed that the effects of exposure to English on the variances of three dependent variables are not high. While the effect of exposure on the variances of writing and the total score are small, it is medium on the variance of speaking.

Table 6. The parameters estimated for the dependent variables.

\begin{tabular}{lccc}
\hline Variable & Effect of Exposure & $\mathrm{r}^{2}$ & $\mathrm{f}^{2}$ (effect size) \\
\hline Writing & $\gamma=.174$ & .032 & .033 (small) \\
Speaking & $\gamma=.405$ & .165 & .198 (medium) \\
Booklet & $\gamma=.364$ & .120 & .136 (small) \\
\hline
\end{tabular}

\section{DISCUSSION and CONCLUSION}

In this study firstly, a scale was developed in order to measure university students' language exposure to English, which has a considerable effect in language acquisition, and secondly, the effect of the language exposure on some components of the English achievement was investigated with a structural model.

The factor structure of the scale was found as six-dimensional. That is to say, the individuals learning English are exposed to English from six different sources which are "Friends \& Family", "Foreigners" (by making contact with friends and with the foreigners speaking English, "School" (in English courses or in courses taught in English), "Media" (by watching series or movies in English), "Text" (by reading books or newspapers in English), and "Computer" (by playing games or using software in English).

According to the results obtained from the structural model, exposure to English has significant effects on writing in English, speaking English and booklet score which is a total score of reading and listening comprehension, grammar and vocabulary knowledge.

In this study, only the variable of exposure to English was included as a predictor of English achievement. In future studies, by using the scale developed in this study, with more complex models, the effect of exposure on English achievement will be investigated with other factors affecting language acquisition. Moreover, these models may also include the factors affecting exposure to English.

This study contributes the existing literature in two important ways. Firstly, although exposure to a language is found to be as an important aspect of language learning, tools to measure the amount of language exposure is limited to the questionnaires (Derwing et all, 2007; Djigunovi'c et al., 2008; Olsson, 2012; Peters, 2018). The questionnaires only allow researchers determine the amount of exposure for each item, but they cannot be used to sum the language exposure, because for these studies construct validity evidence were not performed or reported. The only exception is the study of Gökcan and Çobanoğlu Aktan (2016). Nevertheless, the scale developed in that study aimed to measure the exposure to language for elementary students. Considering the age group of this study, which is university students, a new tool, which reflects the sources of exposure for this age group, was necessary. Moreover, even if some of the items and the sub-scales were similar in the scales for elementary and university students, it was 
necessary to obtain an evidence for the construct validity of the new scale for university students. Secondly, this study contributes the literature in terms of providing evidence for how language exposure is related to speaking and writing language skills by structural equation modeling. This analysis method allows considering the measurement error in the proposed model.

In addition to investigating relation among speaking, writing, and exposure to a language, in future studies relations with other language skills such as reading and listening comprehension in English, as well as grammar and vocabulary knowledge can be investigated. Moreover, a recent study (Kilic, 2018) shows factor scores and the total score are so related to each other that they can be used interchangeably. The factor scores give as much information as the total score about the construct the scale measures. From this point of view, the separate effects of the Exposure to English scale's factors on English achievement can also be studied in future works.

\section{ORCID}

Mustafa Gökcan (DiD https://orcid.org/0000-0002-2284-9967

Derya Çobanoğlu Aktan (iD https://orcid.org/0000-0002-8292-3815

\section{REFERENCES}

Alpar, R. (2011). Çok değişkenli istatistiksel yöntemler [Multivariate statistical methods] (4th ed.). Ankara: Detay Yayıncılık.

Bollen, K. A. (1989). A new incremental fit index for general structural equation models. Sociological Methods \& Research, 17(3), 303-316.

Byrne, B. M. (2010). Structural equation modeling with AMOS: Basic concepts, applications, and programming (2nd ed.). New York: Routledge.

Byrne, B. M. (2012). Structural equation modeling with Mplus: Basic concepts, applications, and programming. New York: Routledge.

Brown, T. (2015). Confirmatory Factor Analysis For Applied Research. (2nd ed.). New York: The Guilford Press.

Can, A. (2014). SPSS ile bilimsel araştırma sürecinde nicel veri analizi [Statistical analysis in scientific research process by SPSS]. Ankara: Pegem Akademi.

Cohen, J. (1988). Statistical Power Analysis for the Behavioral Sciences (2nd ed.). NJ: Lawrence Earlbaum Associates.

Cook, V. (2008). Second language learning and language teaching (4th ed.). London: Hodder Education.

Comrey, A. L., \& Lee, H. B. (1992). A first course in factor analysis. (2nd Edition). New Jersey: Lawrence Erlbaum Associates.

Costello, A. B., \& Osborne, J. W. (2005). Best practices in exploratory factor analysis: Four recommendations for getting the most from your analysis. Practical Assessment, Research \& Evaluation, 10(7), 1-9.

Çokluk, Ö., Şekercioğlu, G. \& Büyüköztürk, Ş. (2014). Sosyal bilimler için çok değişkenli istatistik: SPSS ve LISREL uygulamalart. [Multivariate statistics for social sciences: SPSS and LISREL applications] (3rd ed.) Ankara: Pegem Akademi Yayınları.

Derwing, T. M., Munro, M. J. \& Thomson R. I. (2007). A Longitudinal Study of ESL Learners' Fluency and Comprehensibility Development. Applied Linguistics, 29(3), 359-380.

Djigunovi'c, J. M., Nikolov, M. \& Otto, I. (2008). A comparative study of Croatian and Hungarian EFL students. Language Teaching Research, 12(3), 433-452.

Ellis, R. (2015). Understanding Second Language Acquisition. Oxford: Oxford University Press. 
Gao, S., Mokhtarian, P. L., \& Johnston, R. A. (2008). Nonnormality of data in structural equation models. Transportation Research Record: Journal of the Transportation Research Board, 2082, 116-124.

Gökcan, M., \& Çobanoğlu Aktan, D. (2016). İngilizceye Maruz Kalma Ölçeğinin Geçerlik Ve Güvenirliğinin İncelenmesi [Investigation of the validity and reliability of exposure to English scale]. In N. Akpınar Dellal \& H. Yokuş (Eds), Proceedings of international contemporary educational research congress (pp. 283-294). Ankara: Pegem Akademi.

Gökcan, M. \& Çobanoğlu Aktan, D. (2018). Investigation of the variables related to TEOG English achievement using Language Acquisition Theory of Krashen. Pegem Eğitim ve Ögretim Dergisi, 8(3), 531-566.

Hancock, G. R., \& Schoonen, R. (2015). Structural equation modeling: Possibilities for language learning researchers. Language Learning, 65(S1), 160-184.

Harmer, J. (2007). The practice of English language teaching (4th ed.). Harlow: Pearson Education.

Kilic, A. (2018). Can Factor Scores be Used Instead of Total Score and Ability Estimation?, International Journal of Assessment Tools in Education, 6(1), 25-35.

Kline, R. B. (2016), Principles and practice of structural equation modeling. (4th ed.). New York: The Guilford Press.

Krashen, S. (1982). Principles and practice in second language acquisition. New York: Pergamon Press.

Krashen, S. (2009). The comprehension hypothesis extended. In T. Piske \& M. YoungScholten (Eds), Input Matters in SLA (pp. 81-94). Bristol: Multilingual Matters.

Lightbown, P. M. \& Spada, N. (2006). How languages are learned (3rd ed.). Oxford: Oxford University Press.

Mardia, K. V. (1970). Measures of multivariate skewness and kurtosis with applications. Biometrika, 57(3), 519-530.

Mitchell, R., Myles, F., \& Marsden, E. (2013). Second language learning theories (3rd ed.). London: Routledge.

Muthén, L. \& Muthén, B. (2010) Mplus User's Guide. (6th ed.). Los Angeles, CA: Muthén \& Muthén.

Olsson, E. (2012). "Everything I read on the Internet is in English:" On the impact of extramural English on Swedish 16-year-old pupils' writing proficiency. Licentiate thesis. Gothenburg: Gothenburg University.

Peters E. (2018). The effect of out-of-class exposure to English language media on learners' vocabulary knowledge. ITL - International Journal of Applied Linguistics, 169(1), 142168.

Tabachnick, B. G. \& Fidell, L. S. (2013). Using multivariate statistics. (5th ed.). USA: Pearson Education, Inc.

Thompson, B. (2004). Exploratory and confirmatory factor analysis: Understanding concepts and applications. Washington, DC: American Psychological Association.

UTEXAS (2018). Software faqs. Retrieved July 21, 2018, from https://stat.utexas.edu/softwarefaqs/amos

Winke, P. (2014). Testing Hypotheses about Language Learning Using Structural Equation Modeling. Annual Review of Applied Linguistics, 34, 102-122.

Wolf, S. D., Smit, N. \& Lowie, W. (2017). Influences of early English language teaching on oral fluency. ELT Journal, 71(3), 341-353.

Worthington, R. L., \& Whittaker, T. A. (2006). Scale Development Research: A Content Analysis and Recommendations for Best Practices, The Counseling Psychologist, 34(6), 806-838. 
Appendix 1. First form of the scale

\begin{tabular}{|c|c|c|c|c|c|}
\hline $\begin{array}{l}\text { Aşağıda verilen durumların ne sıklıkla olduğunu, size en } \\
\text { uygun olan ifadeyi gösteren rakamı yuvarlak içine alarak } \\
\text { belirtiniz }\end{array}$ & 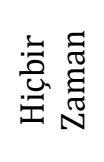 & 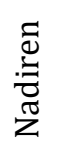 & $\begin{array}{l}\text { Фี } \\
\text { స్ } \\
\text { ஜ }\end{array}$ & 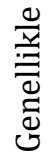 & 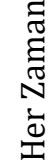 \\
\hline 1. Arkadaşlarım sınıf dışında İngilizce konuşur. & 1 & 2 & 3 & 4 & 5 \\
\hline 2. İngilizcenin konuşulduğu ortamlarda bulunurum. & 1 & 2 & 3 & 4 & 5 \\
\hline 3. Evimizde İngilizce konuşulur. & 1 & 2 & 3 & 4 & 5 \\
\hline 4. Yabancı turistlerle İngilizce konuşurum. & 1 & 2 & 3 & 4 & 5 \\
\hline 5. Yurt dışına seyahat ederim. & 1 & 2 & 3 & 4 & 5 \\
\hline 6. Öğretmenlerim İngilizce konuşur. & 1 & 2 & 3 & 4 & 5 \\
\hline 7. Okulumda İngilizce aktiviteler yapılır. & 1 & 2 & 3 & 4 & 5 \\
\hline 8. Sınıf arkadaşlarım İngilizce konuşur. & 1 & 2 & 3 & 4 & 5 \\
\hline 9. Okulum İngilizce konuşmamızı teşvik eder. & 1 & 2 & 3 & 4 & 5 \\
\hline 10. Okulda dersler İngilizce işlenir. & 1 & 2 & 3 & 4 & 5 \\
\hline 11. İnternet ortamında İngilizce sohbet ederim. & 1 & 2 & 3 & 4 & 5 \\
\hline 12. İngilizce mesajlaşırım (e-mail, sms, whatsapp) & 1 & 2 & 3 & 4 & 5 \\
\hline 13. İnternette İngilizce web sayfalarını okurum. & 1 & 2 & 3 & 4 & 5 \\
\hline 14. İnternette İngilizce blogları takip ederim. & 1 & 2 & 3 & 4 & 5 \\
\hline 15. İngilizce sosyal medya sayfalarını takip ederim & 1 & 2 & 3 & 4 & 5 \\
\hline 16. İngilizce şarkı dinlerim. & 1 & 2 & 3 & 4 & 5 \\
\hline 17. İngilizce dizi izlerim. & 1 & 2 & 3 & 4 & 5 \\
\hline 18. İngilizce film izlerim. & 1 & 2 & 3 & 4 & 5 \\
\hline 19. İngilizce çizgi film- anime izlerim. & 1 & 2 & 3 & 4 & 5 \\
\hline 20. İngilizce televizyon programı izlerim. & 1 & 2 & 3 & 4 & 5 \\
\hline 21. İngilizce youtube videoları izlerim. & 1 & 2 & 3 & 4 & 5 \\
\hline 22. İngilizce dergi okurum. & 1 & 2 & 3 & 4 & 5 \\
\hline 23. İngilizce gazete okurum. & 1 & 2 & 3 & 4 & 5 \\
\hline 24. İngilizce kitap okurum. & 1 & 2 & 3 & 4 & 5 \\
\hline 25. İngilizce karikatür okurum. & 1 & 2 & 3 & 4 & 5 \\
\hline 26. İngilizce bilgisayar oyunu oynarım. & 1 & 2 & 3 & 4 & 5 \\
\hline 27. İngilizce bilgisayar programı kullanırım. & 1 & 2 & 3 & 4 & 5 \\
\hline
\end{tabular}


Appendix 2. Last form of the scale

\begin{tabular}{|c|c|c|c|c|c|c|}
\hline & $\begin{array}{l}\text { Aşağıda verilen durumların ne sıklıkla olduğunu, size en } \\
\text { uygun olan ifadeyi gösteren rakamı yuvarlak içine } \\
\text { alarak belirtiniz }\end{array}$ & 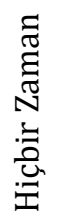 & 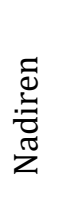 & 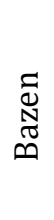 & 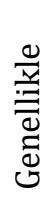 & 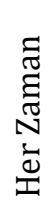 \\
\hline 1 & Arkadaşlarım sınıf dışında İngilizce konuşur. & 1 & 2 & 3 & 4 & 5 \\
\hline 2 & İngilizcenin konuşulduğu ortamlarda bulunurum. & 1 & 2 & 3 & 4 & 5 \\
\hline 3 & Evimizde İngilizce konuşulur. & 1 & 2 & 3 & 4 & 5 \\
\hline 4 & Sınıf arkadaşlarım İngilizce konuşur. & 1 & 2 & 3 & 4 & 5 \\
\hline 5 & Yabancı turistlerle İngilizce konuşurum. & 1 & 2 & 3 & 4 & 5 \\
\hline 6 & Yurt dışına seyahat ederim. & 1 & 2 & 3 & 4 & 5 \\
\hline 7 & Öğretmenlerim İngilizce konuşur. & 1 & 2 & 3 & 4 & 5 \\
\hline 8 & Okulumda İngilizce aktiviteler yapılır. & 1 & 2 & 3 & 4 & 5 \\
\hline 9 & Okulum İngilizce konuşmamızı teşvik eder. & 1 & 2 & 3 & 4 & 5 \\
\hline 10 & Okulda dersler İngilizce işlenir. & 1 & 2 & 3 & 4 & 5 \\
\hline 11 & İngilizce şarkı dinlerim. & 1 & 2 & 3 & 4 & 5 \\
\hline 12 & İngilizce dizi izlerim. & 1 & 2 & 3 & 4 & 5 \\
\hline 13 & İngilizce film izlerim. & 1 & 2 & 3 & 4 & 5 \\
\hline 14 & İnternette İngilizce web sayfalarını okurum. & 1 & 2 & 3 & 4 & 5 \\
\hline 15 & İnternette İngilizce blogları takip ederim. & 1 & 2 & 3 & 4 & 5 \\
\hline 16 & İngilizce dergi okurum. & 1 & 2 & 3 & 4 & 5 \\
\hline 17 & İngilizce gazete okurum. & 1 & 2 & 3 & 4 & 5 \\
\hline 18 & İngilizce kitap okurum. & 1 & 2 & 3 & 4 & 5 \\
\hline 19 & İngilizce karikatür okurum. & 1 & 2 & 3 & 4 & 5 \\
\hline 20 & İnternet ortamında İngilizce sohbet ederim. & 1 & 2 & 3 & 4 & 5 \\
\hline 21 & İngilizce bilgisayar oyunu oynarım. & 1 & 2 & 3 & 4 & 5 \\
\hline 22 & İngilizce bilgisayar programı kullanırım. & 1 & 2 & 3 & 4 & 5 \\
\hline
\end{tabular}


Appendix 3. Normality Test Results

Assessment of normality:

\begin{tabular}{lrrrrrr}
\hline Variable & min & max & skew & c.r. & kurtosis & c.r. \\
\hline B & 20.000 & 91.000 & -.223 & -1.391 & -.480 & -1.495 \\
S & 25.000 & 100.000 & -.238 & -1.486 & -.458 & -1.428 \\
W & 25.000 & 100.000 & -.314 & -1.959 & -.343 & -1.068 \\
M22 & 1.000 & 5.000 & -.238 & -1.483 & -1.288 & -4.013 \\
M19 & 1.000 & 5.000 & .697 & 4.343 & -.702 & -2.187 \\
M18 & 1.000 & 5.000 & .593 & 3.694 & -.353 & -1.100 \\
M17 & 1.000 & 5.000 & 1.366 & 8.513 & 1.199 & 3.736 \\
M16 & 1.000 & 5.000 & .889 & 5.542 & -.042 & -.132 \\
M13 & 1.000 & 5.000 & -1.082 & -6.742 & .232 & .722 \\
M10 & 1.000 & 5.000 & -1.170 & -7.293 & 1.029 & 3.208 \\
M9 & 1.000 & 5.000 & -.554 & -3.453 & -.451 & -1.406 \\
M3 & 1.000 & 5.000 & 1.765 & 11.002 & 3.126 & 9.740 \\
M20 & 1.000 & 5.000 & .339 & 2.114 & -.791 & -2.464 \\
M21 & 1.000 & 5.000 & -.229 & -1.427 & -1.446 & -4.504 \\
M14 & 1.000 & 5.000 & .166 & 1.031 & -.833 & -2.597 \\
M15 & 1.000 & 5.000 & .410 & 2.553 & -.832 & -2.592 \\
M11 & 1.000 & 5.000 & -.940 & -5.859 & .214 & .667 \\
M12 & 1.000 & 5.000 & -1.084 & -6.752 & .280 & .871 \\
M7 & 1.000 & 5.000 & -1.261 & -7.859 & 1.884 & 5.871 \\
M8 & 1.000 & 5.000 & -.530 & -3.303 & -.559 & -1.743 \\
M5 & 1.000 & 5.000 & .428 & 2.670 & -.705 & -2.195 \\
M6 & 1.000 & 5.000 & 1.701 & 10.599 & 1.918 & 5.975 \\
M1 & 1.000 & 5.000 & 1.000 & 6.234 & .780 & 2.431 \\
M2 & 1.000 & 5.000 & .346 & 2.156 & -.324 & -1.010 \\
Multivariate & & & & & 66.221 & 14.307 \\
\hline & & & & & &
\end{tabular}

